\title{
KEKERASAN TERHADAP PEREMPUAN \\ (Mengapa Masyarakat Terbiasa Lecehkan Perempuan ?)
}

\author{
AGUS MAIMUN \\ Dosen Fakultas Tarbiyah UIN Malang
}

\begin{abstract}
Abstrak
Men's subordination towards women still exists in public, social, political, economic as well as cultural areas. Consequently, that kind of social construction negates the representative of women's right due to fear of the present of women's body which trespasses religious and social norms. In fact, any religion and humanity refuse such kinds of discriminition or intimidation towards women. Harassment towards women can be analized through social, moral, emotional, motivational as well as consept of personality perspectives. As the alternative solution for aforementioned problems, efforts can be taken such as reinterpreties religious doctrines based on gender perspective, criticizies sexism myths, socializies gender equality to the society and establish the institution concerning gender issues.
\end{abstract}

\section{A. Pendahuluan}

Apabila kita merenung sejenak, untuk menjernihkan hati dan pikiran, serta selalu bertafakur pada Sang Pencipta, maka nurani kita, superego kita, akan tersentak untuk menelaah kembali budaya patriarkhis, suatu budaya yang telah mendarahdaging dalam lubuk hati masyarakat kita. Betapa memilukannya, jika kita telaah dari segi psikologis, budaya itu lebih menempatkan perempuan pada posisi lemah dan sub-ordinat, sehingga seakan-akan tidak ada rasa persamaan (equality) dan keadilan (equity) antar sesama makhluk Tuhan. Meskipun tidak semua laki-laki melakukan demikian, tetapi wacana yang berkembang mengindikasikan adanya dominasi lakilaki atas perempuan.

Sebagaimana sering kita saksikan dalam tayangan media elektronik atau media cetak, banyak perempuan yang menjadi korban dari budaya tersebut, sehingga mereka terpinggirkan dari suatu komunitas masyarakat. Padahal kalau kita telaah 
secara lebih mendalam, tidak ada satupun nilai-nilai ilahiyah dan insaniyah yang memberikan legitimasi mengenai pelecehan, diskriminasi, dan intimidasi terhadap perempuan.

Membicarakan persamaan dan keadilan gender memang gampang menyulut kontroversi, karena itu berarti memberi kewenangan dan hak pada perempuan untuk menentukan pilihan-pilihan hidupnya secara mandiri. Dalam situasi yang demikian, baik secara sosial, politik, ekonomi, maupun budaya, perempuan masih menjadi subordinatif laki-laki, sehingga tidak terlalu mengherankan bila tuntutan akan hak-hak tubuhnya sendiri itu banyak dikhawatirkan akan "menyalahi" tata aturan moral dan agama.

Uraian berikut akan mendiskripsikan pelecehan perempuan dilihat dari berbagai perspektif, yaitu sosial, moral, motivasi, emosi, konsep diri, dan sikap. Disamping itu, akan dideskripsikan pula mengenai sebab-sebab terjadinya pelecehan terhadap perempuan sekaligus mencari alternatif solusinya.

\section{B. Perspektif Sosial}

Dilihat dari perspektif sosial, pelecehan terhadap perempuan itu merupakan wujud dari sikap non-sosial atau anti sosial. Laki-laki yang non-sosial tidak mengerti perilaku sosial yang dituntut oleh perempuan. Sedang anti-sosial adalah laki-laki non-sosial yang mengetahui hal-hal yang dituntut oleh perempuan, tetapi karena adanya sikap permusuhan atau superior, maka ia melawan dan memusuhi perempuan. Akibatnya, mereka mengabaikan perempuan.

Sikap non-sosial dan anti-sosial ini dipengaruhi oleh fasilitasi sosial dan konflik sosial. Fasilitasi sosial (pengaruh keberadaan orang lain) yang terjadi pada manusia melibatkan proses kognitif yang rumit. Salah satu teori mengatakan bahwa, fasilitasi sosial pada laki-laki bukan semata-mata kehadiran orang lain, tetapi perasaan kompetisi atau diskriminasi. Ada dua teori yang menjelaskan efek fasilitasi sosial, yaitu teori distraksi-konflik dan teori presentasi diri. ${ }^{1}$

\footnotetext{
Erlangga.

${ }^{1}$ Sears, D.O, Freedman, J.L. \& Peplau, L.A. (1999). Psikologi Sosial. (Terj.). Jakarta:
} 
Teori distraksi-konflik menyatakan bahwa, kehadiran orang lain mengalihkan perhatian subyek menyebabkan suatu konflik tentang bagaimana membagi perhatian kepada orang lain dan tugas yang dilakukan. Sedangkan presentasi diri menyatakan bahwa orang lain meningkatkan keinginan individu untuk menampilkan citra yang baik tentang dirinya. Pada tugas yang sulit, keinginan ini memperberat frustasi yang ditimbulkan oleh tugas dan menyebabkan rasa malu, penarikan diri, kecemasan yang berlebihan, yang semuanya menyebabkan kinerja memburuk.

Konflik sosial, sebagaimana yang disajikan dalam berita yang dianalisis ini, menyebabkan terjadinya pelecehan terhadap perempuan. Konflik sosial yang berkembang menjadi perang horisontal, telah menyebabkan banyak korban. Banyak perempuan yang diperkosa pada waktu perang, sehingga mereka tersiksa secara fisik dan mental, bahkan telah terjadi trauma dalam dirinya. Lebih dari itu, banyak dari mereka yang kehilangan suami, karena meninggal dalam peperangan. Dengan tidak ada suami, menjadikan dia harus menjadi kepala rumah tangga, dengan konsekuensi menghidupi semua anaknya. Kondisi yang demikian semakin menambah keprihatinan terhadap perempuan.

Dalam perspektif sosial lainnya, maka pembahasan mengenai relasi laki-laki dan perempuan kata kuncinya adalah demokratisasi. Ketika berbicara demokratisasi, umumnya yang dijadikan obyek perbincangan adalah ruang publik. Padahal ada ruang lain, yaitu ruang domestik, yang selama ini jarang disentuh dalam perbincangan tentang demokratisasi. Demokratisasi di tingkat domestik ini sering rumit. Misalnya, sulitnya menegakkan kehidupan demokratis keluarga berkaitan dengan hak-hak reproduksi perempuan. Kerumitan ini dilatari oleh kuatnya nilainilai budaya atau pandangan agama yang masih konservatif, sehingga kekerasan yang dilakukan suami (laki-laki) di rumah merupakan suatu hal yang biasa. Karena isteri (perempuan) dianggap sebagai "ladang" bagi suami, terserah bagaimana suami memanfaatkan ladang itu. ${ }^{2}$

\section{Perspektif Moral}

\footnotetext{
${ }^{2}$ Hasbianto, E.N. (1999). Kekerasan Dalam Rumah Tangga: Sebuah Kejahatan yang Tersembunyi. Dalam Syafiq Hasyim (Ed.). Menakar "Harga” Perempuan. Bandung: Mizan.
} 
Dilihat dari perspektif moral, pelecehan terhadap perempuan mengindikasikan bahwa, moral tidak berfungsi secara optimal, karena kalau moral berfungsi secara optimal akan menjamin keharmonisan hubungan sosial, menjamin kebahagiaan rohani dan jasmani, memberikan landasan kesabaran untuk dapat bertahan terhadap naluri dan keinginan nafsu, memotivasi berbuat kebajikan, dan memberikan wawasan ke depan.

Hal ini menunjukkan bahwa catexis mewarnai ego, sehingga anti catexis pada superego tidak berfungsi dengan baik. Untuk itu, superego harus diperkuat dengan meletakkan landasan yang kokoh, berupa nilai-nilai ketuhanan dan kemanusiaan. Kalau superego kuat, maka akan ada keseimbangan instink dan kehendak-kehendak yang menjelma dalam suara batin dan tata cara hidup masyarakat. ${ }^{3}$ Agar tata cara hidup masyarakat lebih bermakna, maka harus menyelami secara psikologis masingmasing individu. Setiap orang yang menyelami individu lain, akan senantiasa menimbulkan sikap empati. Dengan demikian, lelaki yang mempunyai sikap empati pada perempuan, jelas tidak akan melakukan pelecehan, apalagi kekerasan.

\section{Perspektif Motivasi}

Dilihat dari perspektif motivasi, orang melakukan pelecehan, diskriminasi, dan intimidasi terhadap perempuan karena ada tujuan-tujuan tertentu. Tujuannya adalah menunjukkan kemahakuasaan laki-laki atas perempuan. Hal ini disebabkan oleh adanya satuan-satuan sosio-budaya dalam masyarakat yang membuat posisi perempuan bukan sekedar termarginalisasi, melainkan tertindas secara nyata oleh dominasi kaum laki-laki ${ }^{4}$.

Tujuan-tujuan tersebut, jika dilihat dari perspektif teori motivasi, termasuk teori hedonisme. Teori ini mengesampingkan rasio. Hedonisme merupakan segala perilaku yang dilakukan untuk mencari hal-hal yang serba menyenangkan. ${ }^{5}$ Dalam konteks ini, laki-laki hanya mencari senangnya saja, tanpa mempertimbangkan penderitaan yang dialami kaum perempuan. Padahal dalam keluarga, isteri sudah

\footnotetext{
${ }^{3}$ Hall,L.S. (1962). Pengantar ke dalam Ilmu Jiwa S. Freud. Terj. S. Tasrif. Jakarta: Pembangunan.

${ }^{4}$ Hasyim, S. (Ed.). (1999). Menakar “Harga” Perempuan. Bandung: Mizan.

${ }^{5}$ Achmad, M. (1985). Etika Dalam Islam. Surabaya: Al-Ikhlas.
} 
mengalami beban fisik dan mental sejak ia mengandung, kemudian melahirkan sampai mengasuh anak-anaknya. Belum lagi ia juga disibukkan kegiatan dapur, kebersihan rumah, bahkan bekerja di luar rumah untuk menambah in-come. Kondisi yang demikian, kalau tidak disadari oleh laki-laki (suami) akan sangat menyakitkan bagi perempuan.

\section{E. Perspektif Emosi}

Dalam perspektif emosi, orang yang melakukan pelecehan terhadap perempuan, berarti emosinya tidak terkendali atau dengan kata lain dia tidak dapat menahan diri atau menguasai diri. Ia selalu dikuasai emosi dan tidak berdaya untuk melepaskan diri, seoalah-olah suasana hatinya telah mengambil alih kekuasaan. Akibatnya, mereka menjadi kurang berupaya melepaskan diri dari suasana hati yang jelek, merasa tidak mempunyai kendali atas emosi mereka. Seringkali dia kalah dan secara emosional lepas kendali. Suatu hal yang aneh, mereka tidak merasa bahwa, akibat perbuatan emosinya itu telah menyebabkan penderitaan bagi orang lain (perempuan). Orang yang demikian berarti tidak mempunyai perasaan sosial. Karena dia telah kehilangan perasaan solidaritas, persaudaraan, simpati, empati, dan kasih sayang. ${ }^{6}$

Untuk mengatasi ini, maka diperlukan kemampuan untuk memanfaatkan emosi secara produktif. Artinya menata emosi sebagai alat untuk mencapai tujuan yang lebih baik. Misalnya melecehkan perempuan yang secara moral dan sosial berbuat salah, seperti WTS. Melecehkan WTS dengan tujuan untuk mengentas WTS dari lembah hitam, merupakan salah satu contoh pemanfaatan emosi secara produktif.

\section{F.Perspektif Konsep Diri.}

Dilihat dari perspektif konsep diri, maka yang muncul adalah konsep diri yang negatif, yang merasa dirinya lebih dari orang lain. ${ }^{7}$ Maksudnya laki-laki merasa

\footnotetext{
${ }^{6}$ Goleman, D. (1999). Kecerdasan Emosional. Alih Bahasa T. Hermaya. Jakarta: Gramedia.

${ }^{7}$ Rakhmat, J. (1999). Psikologi Komunikasi. Edisi Revisi. Bandung: Remaja Rosdakarya.
} 
bahwa dia lebih dari perempuan. Ini sekaligus sebagai refleksi dari rasa mencintai diri sendiri yang berlebihan, sehingga menjadi egois, tidak memperhatikan individu lain (perempuan). Para laki-laki yang demikian, mempunyai tendensi untuk meremehkan perempuan sebagai akibat dari perasaan superior yang dilakukan sebagai kompensasi secara berlebihan. Laki-laki tidak menganggap bahwa perempuan mempunyai hak dan kewajiban yang sama. Konsep diri yang berlebihan dari laki-laki ini, tidak lepas dari kelompok rujukan (reference group), yaitu suatu kelompok yang secara emosional mengikat dan sangat mempengaruhi pembentukan konsep diri. Dalam hal ini, kelompok dimaksud adalah para sesepuh kita yang telah menanamkan budaya patriarkhis secara turun-temurun.

Untuk itu, diperlukan penanaman konsep diri yang positif, berupa penciptaan lingkungan kebersamaan (equilibrium environment), memusatkan perhatian pada kelebihan dan kekurangan masing-masing, menemukan jati diri yang sebenarnya, memformulasikan tujuan hidup bersama, dan menciptakan bahasa yang seimbang antara laki-laki dan perempuan.

\section{G. Perspektif Sikap}

Dilihat dari perspektif sikap, ini merupakan sikap yang ambivalensi. Satu sisi, laki-laki sangat membutuhkan perempuan sebagai "teman hidup" dan memperoleh kehangatan. Tanpa perempuan, laki-laki tidak akan bisa hidup tenang dan terpenuhi segala keinginannya. Lebih jauh lagi, tanpa perempuan laki-laki tidak akan dapat melakukan regenerasi. Namun disisi lain, tidak sedikit laki-laki yang melakukan kekerasan terhadap perempuan. Bahkan kekerasan itu terjadi pada rumah tangga, seperti pemukulan, penganiayaan, dan intimidasi yang berdampak sangat negatif. Dampak negatif tersebut, secara fisik menyebabkan peempuan mengalami patah tulang, kelainan syaraf, memar, kulit tersayat, dan sebagainya. Sedangkan secara psikologis, akan mengalami gangguan emosi, seperti kecemasan, depresi, dan perasaan rendah diri. ${ }^{8}$

\section{H. Mengapa Terjadi Pelecehan Terhadap Perempuan}

\footnotetext{
${ }^{8}$ Hasbiyanto, Kekerasan dalam.............. h.84
} 
Perempuan sebagai "obyek" sering mendapatkan perlakuan yang tidak sepantasnya dari laki-laki. Berbagai tindak kekerasan terhadap perempuan sering kita jumpai dimana-mana, sebagaimana yang dilansir berbagai media massa cetak dan elektronik. Di negara kita, misalnya di Aceh, Maluku, Kalimantan Barat, dan Sulawesi Tengah. Akibat dari perang "saudara" menyebabkan banyak perempuan yang menjadi korban.

Belum lagi adanya berbagai kekerasan dalam rumah tangga (KDRT) yang sebenarnya sangat sering dan gampang terjadi dan tidak diketahui oleh publik. Padahal KDRT justeru banyak yang lebih kejam dari akibat perang. Mengapa terjadi demikian ? Ada beberapa argumen tentang ini, yaitu:

1. Karena adanya ketidaksetaraan sistem dan struktur sosial atas pola relasi laki-laki dan perempuan.

2. Interpretasi yang keliru atas ajaran agama.

3. Pengaruh role model. ${ }^{9}$

Ketiga faktor tersebut ditumbuhkan dan didukung oleh kenyataan bahwa sikap komunitas cenderung mengabaikan persoalan KDRT karena terdapat keyakinan bahwa hal itu merupakan urusan "dalam negeri” suatu rumah tangga. Disamping itu, sistem legal kita juga tidak mempunyai kekuatan khusus guna menekan pelaku KDRT sekaligus melindungi korban.

Ditinjau dari segi psikologi komunikasi, bentuk-bentuk komunikasi dengan kekerasan (terutama kekerasan fisik) merupakan suatu cara pemberian sugesti yang ampuh dan efisien. Itulah sebabnya pemukulan dan bentuk-bentuk kekerasan fisik yang lain sering dipergunakan oleh suami dalam mengakhiri konflik dengan isteri/pasangannya.

KDRT merupakan suatu perilaku yang berulang, mengikuti pola yang khas. Masyarakat tidak menyadari adanya pola ini, sehingga sering terjebak dalam mitos bahwa, perilaku memukul terjadi karena suami "lepas kontrol”. Disamping itu juga, kita sering berpikir bahwa adanya pola yang berulang ini justeru merupakan indikasi adanya gangguan jiwa pada diri suami (pelaku), karena pada saat tertentu ia begitu

\footnotetext{
${ }^{9}$ Ibid, h. 193-194
} 
baik dan menyayangi isterinya, tetapi ketika terjadi konflik ia berubah menjadi “monster” yang menakutkan.

\section{Alternatif Solusi Untuk Mengakhiri Budaya Kekerasan Terhadap Perempuan.}

Ada beberapa cara yang dapat dilakukan untuk mengakhiri budaya kekerasan terhadap perempuan, yaitu:

1. Memberikan tafsir ayat-ayat dalam kitab suci yang berbias gender dengan perspektif gender.

2. Meluruskan mitos-mitos mengenai superioritas laki-laki dan mempopulerkan fakta-faktanya.

3. Mensosialisasikan prinsip kesetaraan antara laki-laki dan perempuan, khususnya dalam konteks hubungan sosial dan keluarga.

4. Penyadaran terhadap masyarakat juga dapat dilakukan dengan mensosialisasikan delik hukum yang berkaitan dengan masalah KDRT.

5. Pembentukan lembaga-lembaga yang peduli atas persoalan ini ${ }^{10}$

\section{J. Penutup.}

Budaya kekerasan terhadap perempuan dengan berbagai sebabnya, harus segera diakhiri. Meskipun pelaksanaannya melalui proses yang panjang, namun harus tetap diperjuangkan, agar terjadi kesetaraan, kesamaan, dan keadilan gender. Untuk memperjuangkan ini, harus ada kolaborasi antar perempuan sendiri dan juga laki-laki yang telah sensitif gender.

Berdasarkan beberapa penelitian yang dilakukan oleh para aktifis perempuan dan LSM yang bergerak dalam pemberdayaan perempuan, menyimpulkan bahwa tindak kekerasan terhadap perempuan sering dilakukan oleh laki-laki yang secara

\footnotetext{
${ }^{10}$ Hasbiyanto,.Kekerasan dalam..........., h.199-200
} 
sosial, ekonomi, budaya, dan pendidikan "terpinggirkan". ${ }^{11}$ Secara sosial, laki-laki yang melakukan demikian kebanyakan dari masyarakat marginal dan strata bawah. Secara ekonomi, mereka yang melakukan demikian adalah dari kalangan masyarakat ekonomi lemah atau kelas bawah. Secara budaya, mereka yang melakukan demikian adalah dari kalangan masyarakat yang masih berpegang pada budaya-budaya tradisional semacam budaya patriarkhis yang mengangxgap wanita sebagai subordinat. Sedang secara pendidikan, mereka yang melakukan demikian adalah dari kalangan masyarakat berpendidikan rendah.

Dengan melihat kenyataan yang demikian, implikasinya adalah masyarakat harus ditingkatkan kualitas hidupnya dalam semua dimensi. Kesemuanya itu, menurut hemat penulis akan bermuara pada pendidikan. Untuk itu, pelayanan pendidikan harus diratakan dan ditingkatkan pada semua masyarakat. Apabila usaha ini dilaksanakan, tidak mustahil kesetaraan gender akan tumbuh subur di republik ini, yang akhirnya akan terjadi harmonisasi dalam keluarga (sakinah, ma waddah wa rohmah). Semoga, amiin.

\section{DAFTAR PUSTAKA}

Achmad, M. (1985). Etika Dalam Islam. Surabaya: Al-Ikhlas.

\footnotetext{
${ }^{11}$ Indraswati (1999). Fenomena Kawin Muda dan Aborsi: Gambaran Kasus. Dalam Syafiq Hasyim (Ed.). Menakar “Harga” Perempuan. Bandung: Mizan.
} 
Goleman, D. (1999). Kecerdasan Emosional. Alih Bahasa T. Hermaya. Jakarta: Gramedia.

Hasbianto, E.N. (1999). Kekerasan Dalam Rumah Tangga: Sebuah Kejahatan yang Tersembunyi. Dalam Syafiq Hasyim (Ed.). Menakar "Harga" Perempuan. Bandung: Mizan.

Hall,L.S. (1962). Pengantar ke dalam Ilmu Jiwa S. Freud. Terj. S. Tasrif. Jakarta: Pembangunan.

Hasyim, S. (Ed.). (1999). Menakar "Harga” Perempuan. Bandung: Mizan.

Indraswati (1999). Fenomena Kawin Muda dan Aborsi: Gambaran Kasus. Dalam Syafiq Hasyim (Ed.). Menakar "Harga" Perempuan. Bandung: Mizan.

Kohlberg, L. (1981). Essays on Moral Development. Vol.I, The Philosophy of Moral Development, Moral Stages and The Idea of Justice. San Fransisco: Harper and Row.

Rakhmat, J. (1999). Psikologi Komunikasi. Edisi Revisi. Bandung: Remaja Rosdakarya.

Sears, D.O, Freedman, J.L. \& Peplau, L.A. (1999). Psikologi Sosial. (Terj.). Jakarta: Erlangga.

Yusuf, S. (2000). Psikologi Perkembangan, Anak \& Remaja. Bandung: Remaja Rosdakarya. 